\title{
Article \\ A Combined Vermifiltration-Hydroponic System for Swine Wastewater Treatment
}

\author{
Kirill Ispolnov ${ }^{1, *}$, Luis M. I. Aires ${ }^{1}$, Nídia D. Lourenço ${ }^{2} \mathbb{D}$ and Judite S. Vieira ${ }^{1}$ (D) \\ 1 Laboratory of Separation and Reaction Engineering-Laboratory of Catalysis and Materials (LSRE-LCM), \\ School of Technology and Management (ESTG), Polytechnic Institute of Leiria, 2411-901 Leiria, Portugal; \\ luis.aires@ipleiria.pt (L.M.I.A.); judite.vieira@ipleiria.pt (J.S.V.) \\ 2 Applied Molecular Biosciences Unit (UCIBIO)-REQUIMTE, Department of Chemistry, NOVA School of \\ Science and Technology (FCT), NOVA University of Lisbon, 2829-516 Caparica, Portugal; \\ nidia.lourenco@fct.unl.pt \\ * Correspondence: kirill.ispolnov@ipleiria.pt
}

Citation: Ispolnov, K.; Aires, L.M.I.; Lourenço, N.D.; Vieira, J.S. A

Combined Vermifiltration-Hydroponic System for Swine Wastewater Treatment. Appl. Sci. 2021, 11, 5064. https://doi.org/10.3390/app11115064

Academic Editor: Bart Van der Bruggen

Received: 27 April 2021

Accepted: 28 May 2021

Published: 30 May 2021

Publisher's Note: MDPI stays neutral with regard to jurisdictional claims in published maps and institutional affiliations.

Copyright: (c) 2021 by the authors. Licensee MDPI, Basel, Switzerland. This article is an open access article distributed under the terms and conditions of the Creative Commons Attribution (CC BY) license (https:/ / creativecommons.org/licenses/by/ $4.0 /)$.

\begin{abstract}
Intensive swine farming causes strong local environmental impacts by generating effluents rich in solids, organic matter, nitrogen, phosphorus, and pathogenic bacteria. Insufficient treatment of hog farm effluents has been reported for common technologies, and vermifiltration is considered a promising treatment alternative that, however, requires additional processes to remove nitrate and phosphorus. This work aimed to study the use of vermifiltration with a downstream hydroponic culture to treat hog farm effluents. A treatment system comprising a vermifilter and a downstream deep-water culture hydroponic unit was built. The treated effluent was reused to dilute raw wastewater. Electrical conductivity, $\mathrm{pH}$, and changes in $\mathrm{BOD}_{5}$, ammonia, nitrite, nitrate, phosphorus, and coliform bacteria were assessed. Plants were monitored throughout the experiment. Electrical conductivity increased due to vermifiltration; $\mathrm{pH}$ stayed within a neutral to mild alkaline range. Vermifiltration removed $83 \%$ of $\mathrm{BOD}_{5}, 99 \%$ of ammonia and nitrite, and increased nitrate by $11 \%$. Hydroponic treatment removed $\mathrm{BOD}_{5}(63 \%)$, ammonia $(100 \%)$, nitrite $(66 \%)$, nitrate $(27 \%)$, and phosphorus ( $47 \%$ total and $44 \%$ dissolved) from vermifiltered water. Coliforms were reduced by vermifiltration but recovered in the hydroponic unit. Plants showed the ability to grow on vermifiltered wastewater, although requiring nutrient supplementation. Vermifiltration combined with hydroponics is a promising treatment for swine wastewater, although optimization will be needed for a sustainable real-scale implementation.
\end{abstract}

Keywords: hog farm wastewater; vermifilter; hydroponic cultures

\section{Introduction}

Pork consumption has been steadily increasing worldwide. According to the Food and Agriculture Organization of the United Nations (FAO), 110.1 million tons of pork meat were produced worldwide in 2019, of which 29.7 million tons are in Europe and 387.9 thousand tons in Portugal [1]. Pork consumption in Portugal reached $43.4 \mathrm{~kg}$ in 2017, $44.7 \mathrm{~kg}$ in 2018 , and $44.3 \mathrm{~kg}$ in 2019 by inhabitant [2]. A large consumer-producer ratio leads to a more intensive production on larger scales, thereby concentrating the hog breeding and the resulting impacts on relatively small areas [3]. A study of 168 Chinese small-scale hog farms reported median values of 216 tons/year of produced manure, 333 tons/year of urine, and 773 tons/year of washing wastewater [4]. Hog farm wastewaters were reported to contain, per dry weight, 6.3 to $11.6 \%$ of total nitrogen (TN) and 3.3 to $8.9 \%$ ammonia nitrogen $\left(\mathrm{NH}_{3}-\mathrm{N}\right), 1.7$ to $4.4 \%$ total phosphorus (TP) and 2.2 to $5.5 \%$ total potassium [5]. Liquid swine manure was also found to contain large amounts of total suspended solids (TSS), total phosphorus (TP), total Kjeldahl nitrogen (TKN), total organic carbon (TOC), high chemical oxygen demand (COD), and 5-day biochemical oxygen demand $\left(\mathrm{BOD}_{5}\right)$ prior to treatment [6]. Swine wastewaters were reported to be a source of copper and zinc 
pollution [4] and to carry large amounts of coliform bacteria [6]. If left untreated, swine manure will contaminate surface waters, soils, and groundwaters, posing threats to public health and to the environment by causing ecotoxicity and water eutrophication.

The simplest way to treat swine manures and wastewaters is to use them directly as soil fertilizer. However, this is not the best option, as the bioavailability of nutrients in manures to agricultural crops was found to be limited (only $20 \%$ of N, $40 \%$ of $\mathrm{P}_{2} \mathrm{O}_{5}$ and $29 \%$ of $\mathrm{K}_{2} \mathrm{O}$ available) [7]. Agricultural reuse of untreated wastewaters can alter soil $\mathrm{pH}$, increase organic compounds, salinity, nitrogen, metals and emerging contaminants, and change microbial community structure and activities [8]. Most commonly, swine manures are treated in loco by temporary deposition in non-aerated lagoons for decomposition of organic matter, with or without previous removal of solids. The low cost of this treatment technique [9] makes it attractive and widely used. Lagoon treatment is, however, ineffective, as it fails to remove and rather increases inorganic nitrogen and phosphorus contaminants [10]. Furthermore, lagoons have a limited holding capacity; if uncovered, they are prone to overflowing under heavy precipitation. Aerated lagoons are more efficient as they promote nitrification, eliminate toxic substances and foul odours, but aeration makes them much more expensive [9,10]. Additional treatments have been studied, including composting of solids [9], overland flow through artificial isolated plots of soil with vegetation [10], constructed wetlands [11], controlled digester tanks [9], trickling filters [10], and immobilized nitrifying bacteria culture reactors [10]. Overland flows and constructed wetlands have proven to be naturally limited $[10,11]$, while more technological treatments are more expensive $[9,10]$. Vermicomposting of manures [12] and vermifiltration of swine wastewaters [13] are examples of cheap nature-based treatments for hog farm wastes. Earthworm activity is complex and involves a multitude of processes: (1) mechanical mixing, aeration, and reduction of particles to smaller size through burrowing and grinding, with the advantages of increased surface area, improved filtration efficiency, and sorption; (2) chemical and biochemical effects of digestion and biologically active substances excreted with the vermicast; (3) inoculation of the substrate with earthworm gut bacteria [14,15]. Earthworm treatment increases dissolved oxygen content due to the worms' burrowing action $[14,16]$ and removes organic matter from different types of waste and wastewater: up to 58 to $63 \%$ TOC $[17,18], 98$ to $99 \% \mathrm{BOD}_{5}$, and 70 to $100 \%$ COD [19-21]. Earthworm treatments have also been shown to remove ammonia up to $67 \%$ by vermicomposting [22] and up to $97 \%$ by vermifiltration [20] and increase nitrate up to $75 \%$ by vermicomposting and $187 \%$ by vermifiltration [22]. The C:N ratio has been reported to decrease in solid and liquid wastes treated by earthworms due to the loss of carbon as $\mathrm{CO}_{2}[12,17]$. Earthworms alter microbial communities, favoring betaproteobacteria [23-25], which include ammoniaoxidizing bacteria $(\mathrm{AOB})$, nitrite-oxidizing bacteria (NOB) and some denitrifiers [26]; on the other hand, fungi such as Candida albicans, Aspergillus flavus and Aspergillus niger [27] and pathogenic bacteria Bacillus sp., E. coli, Serratia marcescens [28], Pseudomonas aeruginosa, Klebsiella pneumoniae, Staphylococcus aureus and Streptococcus pyogenes [27] are suppressed.

A drawback of earthworm waste and wastewater treatments is the reported increase of nitrate [22,29] and phosphorus [22,30,31], increasing the risk of eutrophication by the effluents. Thus, further downstream treatment is needed to remove these contaminants. Hydroponic (soil-less) plant-based treatments have been shown to effectively remove nitrate and inorganic phosphorus, among other contaminants, from different types of wastewaters and, in particular, swine wastewaters [32-34]. Combining earthworms with downstream hydroponic cultures has been recently proposed [35] and is a promising technology for efficient treatment of wastewaters such as those from hog farms.

The present study aimed to build and test an indoor pilot-scale swine wastewater treatment system comprising a vermifiltration unit for the removal of ammonia, nitrite, organic matter, and pathogens with a downstream hydroponic plant cultivation unit for further removal of nitrate and phosphorus with the concomitant production of marketable crops. 


\section{Materials and Methods}

\subsection{Raw Wastewater}

The raw wastewater for vermifiltration/hydroponic treatment was obtained from a piggery located in Leiria district, as grab samples collected monthly from the second of a system of three sequential anaerobic/facultative lagoons, to represent an intermediate stage of initial treatment. Larger solids were filtered through a 1.2-mm mesh colander; the remaining solids were allowed to settle in the bottles after transportation, and the supernatant was decanted. Raw wastewater collected from the selected lagoon had been previously characterized [36] as described in Table 1.

Table 1. Physical and chemical parameter values of the raw piggery wastewater collected from the selected lagoon [36]. TDS: total dissolved solids; TSS: total suspended solids; EC: electrical conductivity; $\mathrm{COD}$ : chemical oxygen demand; $\mathrm{BOD}_{5}$ : 5-day biochemical oxygen demand; $\mathrm{NH}_{3}-\mathrm{N}$ : ammonia nitrogen; $\mathrm{NO}_{2}-\mathrm{N}$ : nitrite nitrogen; $\mathrm{NO}_{3}-\mathrm{N}$ : nitrate nitrogen; TP: total phosphorus; $\mathrm{PO}_{4}-\mathrm{P}$ : free phosphate phosphorus.

\begin{tabular}{cc}
\hline Parameter & Value \\
\hline TDS & $3100 \mathrm{mg} / \mathrm{L}$ \\
$\mathrm{TSS}$ & $1900 \mathrm{mg} / \mathrm{L}$ \\
$\mathrm{EC}$ & $0.9000 \mathrm{~S} / \mathrm{m}$ \\
$\mathrm{pH}$ & 8.00 \\
$\mathrm{COD}$ & $1997 \mathrm{mgO}_{2} / \mathrm{L}$ \\
$\mathrm{BOD}_{5}$ & $149 \mathrm{mgO}_{2} / \mathrm{L}^{1}$ \\
$\mathrm{NH}_{3}-\mathrm{N}$ & $574 \mathrm{mg} / \mathrm{L}$ \\
$\mathrm{NO}_{2}-\mathrm{N}$ & $0.034 \mathrm{mg} / \mathrm{L}$ \\
$\mathrm{NO}_{3}-\mathrm{N}$ & $1.50 \mathrm{mg} / \mathrm{L}$ \\
$\mathrm{TP}^{-}$ & $159 \mathrm{mg} / \mathrm{L}$ \\
$\mathrm{PO}_{4}-\mathrm{P}$ & $34.0 \mathrm{mg} / \mathrm{L}$ \\
\hline
\end{tabular}

$\overline{{ }^{1} \text { The unusually low } \mathrm{BOD}_{5} \text { value could be explained by oxidation within the holding lagoon system, since the }}$ residence times at sample collection moments were variable.

\subsection{System Setup}

The experimental system for this study (Figures 1 and 2) comprised a raw wastewater reservoir, a wastewater mixing tank, a trap for the retention of larger solids, the vermifilter, the hydroponic deep-water culture (DWC) unit, and a final reservoir for treated water.

The mixing tank was a cylindrical 160 liter barrel containing a total liquid volume of $100 \mathrm{~L}$, stirred by a $120 \mathrm{~W}$ CAT R50 overhead stirrer with a four-flat-blade impeller (diameter $100 \mathrm{~mm}$, blade width $50 \mathrm{~mm}$ ) at $120 \mathrm{rpm}$, that served to dilute the raw wastewater in order to decrease its starting EC values, since less than $1 \mathrm{~S} / \mathrm{m}$ has been found to cause total mortality in Eisenia fetida [37]. From there, diluted wastewater was pumped by a Heidolph Pumpdrive 5101 peristaltic pump at $11 \mathrm{~L}$ /day through a 4-mm plastic tube, trickling onto the top of the vermifilter unit.

The vermifilter was constructed based on previously described models [21,38]. An opaque plastic cylinder (total height $63 \mathrm{~cm}$, internal diameter $16 \mathrm{~cm}$ ) with 4-mm lateral perforations for aeration in the lower half, $6 \mathrm{~cm}$ apart, was filled bottom to top with 22.4 by $45 \mathrm{~mm}$ gravel $(10 \mathrm{~cm}), 16$ by $22.4 \mathrm{~mm}$ gravel $(7.5 \mathrm{~cm}), 6.3$ by $14 \mathrm{~mm}$ gravel $(7.5 \mathrm{~cm})$, 2.0 by $6.3 \mathrm{~mm}$ gravel $(5 \mathrm{~cm})$, coarse river sand $(3 \mathrm{~cm})$, fine river sand $(10 \mathrm{~cm})$, and a 15 $\mathrm{cm}$ layer of a 1:2 mixture (by apparent dry volume) of Earthworm humus (Siro ${ }^{\mathrm{TM}}$ ) with pine wood chips from a local sawmill. This last layer was inoculated with live Eisenia fetida earthworms ranging from 3 to $6 \mathrm{~cm}$ in length $\left(10\right.$ to $\left.12 \mathrm{~g} / \mathrm{dm}^{3}\right)$. The worms were initially supplied by a private breeder and were bred in a houseplant pot filled with soil and topped with regularly renovated vegetable waste. Water flowed through the vermifilter by gravity, trickling into the hydroponic unit placed below. It was ensured that the flow through the vermifilter was free enough to be set by the peristaltic pump alone. 


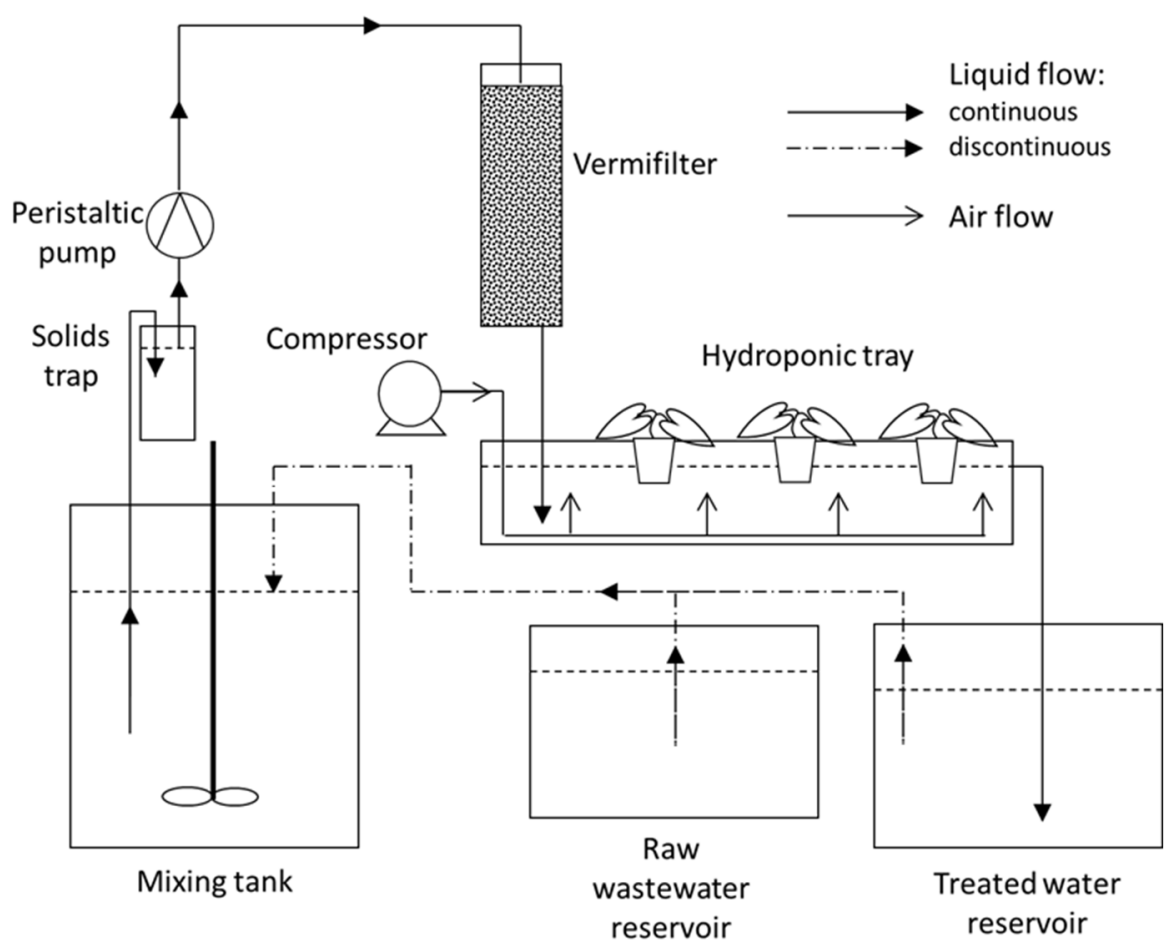

Figure 1. Schematic representation of the built vermifiltration-hydroponic system. Arrows indicate the liquid and air flow directions.

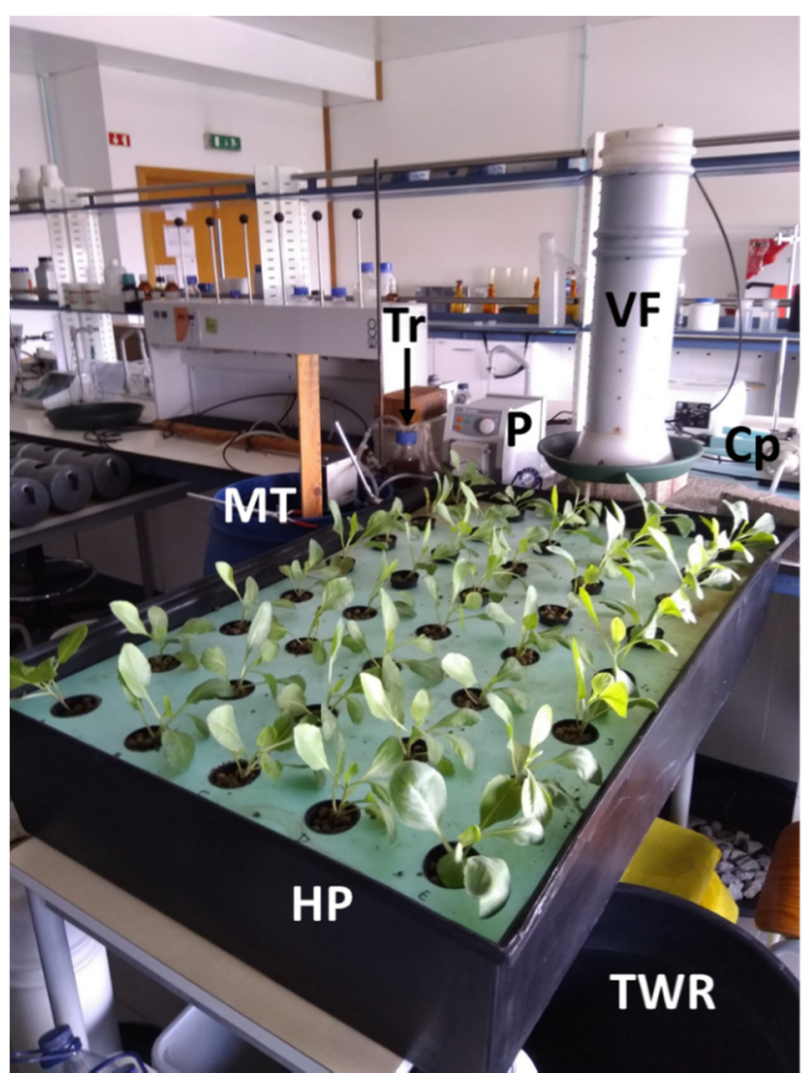

Figure 2. Vermifiltration-hydroponic system. Cp: air compressor; HP: hydroponic tray; MT: mixing tank; P: peristaltic pump; Tr: trap for solids; TWR: treated water reservoir; VF: vermifilter.

The DWC hydroponic unit consisted of a rectangular $120 \mathrm{~cm}$ long, $80 \mathrm{~cm}$ wide, $25 \mathrm{~cm}$ high black plastic tray. Aeration was ensured by a grid of perforated $4 \mathrm{~mm}$ plastic tubes 
disposed in 20-cm side squares, fed by a $60 \mathrm{~W}, 70 \mathrm{~L} / \mathrm{min}$ Hailea ACO-328 air compressor. A standpipe of defined height placed on exit allowed for controlling the total volume and hydraulic residence time for a constant volumetric flow. Two polystyrene foam rafts were placed on top of the container, floating directly on water surface. The effective liquid volume in the completely assembled unit under aeration was measured to be $114 \mathrm{~L}$. Therefore, the hydraulic residence time (HRT) was estimated to be 10.4 days on average. The hydroponic unit was illuminated by diffuse natural light from the laboratory windows.

The vermifilter was pre-operated alone for 60 days to allow the earthworms to get acclimated to swine wastewater, before the plants were introduced in the hydroponic unit. The selected crop (pointed cabbage, Brassica oleracea L., var. capitata) was previously tested among other cultures, having showed survival and visible growth on the vermifiltered swine wastewater. The cabbages were planted in plastic net pots (diameter $55 \mathrm{~mm}$, Bulsø Plastics, Denmark) filled with light expanded clay aggregate (LECA) for root support. The pots were placed in holes of appropriate diameter made in the rafts, $13 \mathrm{~cm}$ apart. The crops for hydroponic growth were purchased at a local agricultural supply store (Agriloja, Leiria, Portugal). As the young plants had been growing in soil-filled cuvettes at the moment of purchase, their roots were washed of soil before placing them in the net pots and securing with LECA.

Water exiting the hydroponic growth module was stored in a $75 \mathrm{~L}$ reservoir, from where it was returned to the mixing container to dilute the raw wastewater, in order to promote the system sustainability by saving water. The dilution was performed by manual transfer every seven days from the end reservoir to the mixing tank with the addition of raw piggery wastewater in the proportion 9:1 (treated water: raw wastewater) or, when treated water dilution was necessary, a proportion of 8:1:1 (treated water: clean water: raw wastewater) was used instead. The rest of the volume in the end reservoir was considered the final treated water and was removed from the system.

\subsection{Water Physical and Chemical Analysis}

Samples were collected for analysis from the vermifilter feed, the vermifilter effluent, and the hydroponic growth container, on the day after the addition of a new portion of piggery effluent to the mixing tank.

Electrical conductivity $(\mathrm{EC})$ and $\mathrm{pH}$ were measured directly by electrometric equipment. EC was measured by an Edge HI2030 conductometer connected to an HI763100 cell (Hanna Instruments). For pH measurements, a pH212 potentiometer with an HI1131 selective hydrogen electrode was used (Hanna Instruments).

5 -day biochemical oxygen demand $\left(\mathrm{BOD}_{5}\right)$ was determined in water samples according to the International Standard ISO 5815-1:2019 [39].

Nitrate was determined by the brucine colorimetric method according to the United States Environment Protection Agency (EPA) Method 352.1, with potassium nitrate used as a standard for calibration curves [40]. Nitrite $\left(\mathrm{NO}_{2}-\mathrm{N}\right)$ was determined colorimetrically according to the Standard Method for the Examination of Water and Wastewater (SMEWW) $4500-\mathrm{NO}_{2}{ }^{-}$.B; calibration curves were produced using sodium nitrite as standard [41]. Ammonia nitrogen $\left(\mathrm{NH}_{3}-\mathrm{N}\right)$ was determined colorimetrically according to the international standard ISO 7150-1:1984; calibration curves were made with ammonium chloride as standard [42]. Dissolved phosphorus was determined colorimetrically according to SMEWW-P E [41], with dihydrogen phosphate as standard, after filtration; total phosphorus was determined by the same method after digestion with 1:50 of concentrated sulphuric acid and 1:10 of concentrated nitric acid, heating until volume reduction to less than $20 \%$ and neutralizing with $1 \mathrm{~mol} / \mathrm{L} \mathrm{NaOH}$, a procedure based on SMEWW-P E [41]. For all colorimetric determinations, the samples were previously filtered through Whatman Reeve Angel 0.8-0.9 $\mu \mathrm{m}$ pore diameter glass fiber filters, followed by Neoreax or Normax 0.45 $\mu \mathrm{m}$ pore diameter cellulose acetate or mixed cellulose esters (MCE) membranes to remove suspended solids. 
All determinations were performed in triplicate for each sample, unless stated otherwise. Standard concentrations were defined previously to present a good linearity (determination coefficients higher than 0.99 ) over an interval where a diluted or undiluted sample could fall. Sample concentration values were considered below the limit of quantification (LOQ) when undiluted samples yielded absorbance values below the lowest concentration calibration standard $\left(0.05 \mathrm{mgNH}_{3}-\mathrm{N} / \mathrm{L}, 0.005 \mathrm{mgNO}_{2}-\mathrm{N} / \mathrm{L}, 1 \mathrm{mgNO}_{3}-\mathrm{N} / \mathrm{L}\right.$, or $0.100 \mathrm{mgP} / \mathrm{L}$ for both total and dissolved phosphorus).

Relative change $(\mathrm{RC})$ of each parameter through treatment in each stage was calculated using the formula:

$$
\mathrm{RC}=\frac{\mathrm{x}_{\mathrm{eft}}-\mathrm{x}_{\mathrm{feed}}}{\mathrm{x}_{\mathrm{feed}}} \times 100 \%,
$$

where $\mathrm{x}_{\text {feed }}$ represents a parameter value in the feed, and $\mathrm{x}_{\mathrm{eft}}$ is the corresponding value in the effluent in each treatment stage. Since the HRT resulted in being longer than the 7-day periods between manual wastewater dilutions, feed concentrations were calculated as average of values from the last three analysis dates (also 7 days apart), weighted for the time each concentration had been fed into the system.

Standard error of the mean, or simply standard error (SE), was used as an uncertainty measure in all calculations.

To test the significance of changes due to the treatment, an analysis of variance (ANOVA) was performed. $p$-values indicate the probability of the null hypothesis to be true (parameter values at the end of a treatment being equal to those at the start). Significance was considered low for $p>0.05$ and very low for $p>0.50$.

\subsection{Coliform Bacteria}

Coliforms were quantified in water on different stages of treatment by a standard serial 10 -fold dilutions method. Known volumes of undiluted $(0.300 \mathrm{~mL})$ or diluted sample $(1.00 \mathrm{~mL})$ were filtered through sterile Normax $0.45 \mu \mathrm{m}$ pore diameter mixed cellulose esters (MCE) membranes, inoculated on sterile Millipore Coliform ChromoSelect Agar plates, and incubated at $37^{\circ} \mathrm{C}$ for $48 \mathrm{~h}$ prior to counting of the colored colonies [43]. Their number was considered to correspond to the number of colony-forming units (CFU) on each plate.

\subsection{Hydroponic Growth Monitoring}

The hydroponic crops' survival, health, and nutrition were monitored weekly by assessing their growth and overall look. Measurements were performed with a tape measure. Apparent stem length was calculated as stem length measured above the LECA level plus $2 \mathrm{~cm}$ to account for the estimated length covered by the LECA. Apparent total aerial length was calculated as aerial length measured above the LECA level plus $2 \mathrm{~cm}$. Apparent leaf span diameter was measured as the widest observed leaf span perpendicularly to the stem, excluding the dead leaf tips when present. All the measurements were rounded to $0.5 \mathrm{~cm}$. The number of leaves was counted considering all the observable leaves, excluding those with more than $50 \%$ dead area.

\section{Results and Discussion}

\subsection{Electrical Conductivity and $p H$}

Electrical conductivity (EC) and $\mathrm{pH}$ values, measured over time in the feed, the vermifilter effluent, and the hydroponic unit effluent, are presented in Table 2. An increase in EC was observed, most noticeably from the feed to the effluent of the vermifilter on day 21. EC has been previously reported to increase in vermifiltered wastewaters due to organic matter mineralization $[15,22]$. The reason for a much lower EC in the feed than in the other samples of that day is unclear. Subsequent measurements showed relatively high EC values till day 42. $\mathrm{pH}$ showed neutral to slightly alkaline values, higher in the vermifilter effluent and hydroponic effluent. 
Table 2. EC and pH single readings in the Vermifiltration-hydroponic system. VF: vermifilter; HP: hydroponic unit.

\begin{tabular}{|c|c|c|c|c|c|c|}
\hline \multirow{2}{*}{ Time (Days) } & \multicolumn{3}{|c|}{$\mathrm{EC}(\mathrm{S} / \mathrm{m})$} & \multicolumn{3}{|c|}{$\mathrm{pH}$} \\
\hline & VF Feed & VF Effluent/HP Feed & HP Effluent & VF Feed & VF Effluent/HP Feed & HP Effluent \\
\hline 21 & 0.1610 & 0.3050 & 0.2928 & 6.72 & 7.34 & 7.65 \\
\hline 28 & 0.2237 & 0.2413 & 0.2776 & 7.38 & 7.60 & 7.77 \\
\hline 35 & 0.2475 & 0.2517 & 0.2989 & 7.02 & 7.61 & 7.77 \\
\hline 42 & 0.2901 & 0.2940 & 0.2642 & 6.52 & 7.25 & 7.69 \\
\hline 49 & 0.1591 & 0.1635 & 0.1605 & 6.87 & 7.71 & 7.71 \\
\hline
\end{tabular}

According to a 2016 technical report produced at Oklahoma State University, EC ranging from $0.25 \mathrm{~S} / \mathrm{m}$ to $0.30 \mathrm{~S} / \mathrm{m}$ should be optimal for cabbage (unspecified variety); optimal pH was reported to be between 6.5 and 7.0 [44]. On the other hand, increasing salinity has been reported to impair nitrogen, potassium, calcium and magnesium leaf concentrations in Chinese cabbage, with nitrogen and potassium remaining stable at EC from 0.22 to $0.52 \mathrm{~S} / \mathrm{m}$ [45], so some metabolic damage on the crops might still result. For Eisenia fetida, negative effects of high EC on survival and growth were reported, the $50 \%$ lethal dosage after 42 days being $0.183 \mathrm{~S} / \mathrm{m}$ [46]. Alkaline conditions promote the deprotonation of ammonia to its toxic form $\mathrm{NH}_{3}$, which might also affect the earthworms; however, a study of both ammonia and $\mathrm{pH}$ increase on a vermifiltration system reported little to no negative effects on the operation [47]. In this study, the measured $\mathrm{pH}$ ranged from 6.5 to 7.8 . These values could benefit nitrification activity since optimal ammonia and nitrite oxidation in polluted waters have been reported to occur at $\mathrm{pH}$ between 6.5 and 7.5 [48]. According to Portuguese law, the final $\mathrm{pH}$ values fell within the limit values for wastewater discharge (6 to 9 ) and the recommended values for irrigation (6.5 to 8.4); however, EC values in all system samples exceeded the recommended for irrigation $(0.1 \mathrm{~S} / \mathrm{m})[49]$.

\subsection{Biochemical Oxygen Demand $\left(B O D_{5}\right)$, Nitrogen, and Phosphorus}

Biochemical oxygen demand $\left(\mathrm{BOD}_{5}\right)$, nitrogen, and phosphorus were determined in the system starting on day 28 , when the plants had reached their maximum size. $\mathrm{BOD}_{5}$ and different forms of inorganic nitrogen in the vermifilter feed and effluent, as well as their relative change due to treatment by vermifiltration, are shown in Table 3 for the best vermifiltration performance attained during the reported experimental period. Results for $\mathrm{BOD}_{5}$, inorganic nitrogen, and total and dissolved phosphorus in the hydroponic treatment feed, effluent, and relative change are presented in Table 4 for the best hydroponic performance attained during the reported experimental period.

Table 3. Vermifiltration treatment feed, effluent, and relative change (RC) in water quality parameters. The results are presented as triplicate $(n=3)$ mean \pm standard error.

\begin{tabular}{ccccc}
\hline & Feed & Effluent & RC (\%) & $p$-Value \\
\hline $\mathrm{BOD}_{5}\left(\mathrm{mgO}_{2} / \mathrm{L}\right)$ & $35.1( \pm 0.3)$ & $5.8( \pm 0.3)$ & $-83( \pm 2)$ & $<0.001$ \\
$\mathrm{NH}_{3}-\mathrm{N}(\mathrm{mgN} / \mathrm{L})$ & $8.9( \pm 0.5)$ & $0.075( \pm 0.004)$ & $-99( \pm 7)$ & $<0.001$ \\
$\mathrm{NO}_{2}-\mathrm{N}(\mathrm{mgN} / \mathrm{L})$ & $2.19( \pm 0.01)$ & $0.0307( \pm 0.0002)$ & $-98.6( \pm 0.4)$ & $<0.001$ \\
$\mathrm{NO}_{3}-\mathrm{N}(\mathrm{mgN} / \mathrm{L})$ & $173( \pm 1)$ & $192( \pm 1)$ & $+11.0( \pm 0.8)$ & $<0.001$ \\
\hline
\end{tabular}


Table 4. Hydroponic treatment feed, effluent, and relative change (RC) in water quality parameters. The results are presented as triplicate $(n=3)$ mean \pm standard error.

\begin{tabular}{ccccc}
\hline & Feed & Effluent & RC (\%) & $p$-Value \\
\hline $\mathrm{BOD}_{5}\left(\mathrm{mgO}_{2} / \mathrm{L}\right)$ & $5.9( \pm 0.7)$ & $2.17( \pm 0.08)$ & $-63( \pm 15)$ & $<0.001$ \\
$\mathrm{NH}_{3}-\mathrm{N}(\mathrm{mgN} / \mathrm{L})$ & $0.075( \pm 0.004)$ & $<\mathrm{LOQ}$ & -100 & - \\
$\mathrm{NO}_{2}-\mathrm{N}(\mathrm{mgN} / \mathrm{L})$ & $0.0329( \pm 0.0013)$ & $0.0112( \pm 0.0012)$ & $-66( \pm 6)$ & $<0.001$ \\
$\mathrm{NO}_{3}-\mathrm{N}(\mathrm{mgN} / \mathrm{L})$ & $208( \pm 13)$ & $153( \pm 1)$ & $-27( \pm 3)$ & $<0.001$ \\
$\mathrm{TP}(\mathrm{mgP} / \mathrm{L})$ & $39.2( \pm 0.9)$ & $20.9( \pm 0.4)$ & $-47( \pm 3)$ & $<0.001$ \\
$\mathrm{PO}_{4}-\mathrm{P}(\mathrm{mgP} / \mathrm{L})$ & $33.2( \pm 0.3)$ & $18.5( \pm 0.3)$ & $-44( \pm 1)$ & $<0.001$ \\
\hline
\end{tabular}

\subsubsection{Biochemical Oxygen Demand}

Over the reported four-week period, the vermifiltration unit showed the ability to remove between 66 and $83 \%$ of the influent $\mathrm{BOD}_{5}$, which is consistent with removal values reported in the literature for various wastes [19-22]. Although fluctuations were observed, the unit showed the capacity to remove close to $80 \%$ of $\mathrm{BOD}_{5}$ at 28,42 , and 49 days of operation. According to the Portuguese law, the maximum allowed $\mathrm{BOD}_{5}$ value for discharge from a wastewater treatment plant is $25 \mathrm{mgO}_{2} / \mathrm{L}$, and the removal efficiency should be at least 70\% [50]. The observed removal of $\mathrm{BOD}_{5}$ by vermifiltration generally met the national legal requirements. A further significant decrease of organic matter measured as $\mathrm{BOD}_{5}$ was observed in the hydroponic unit after the initial removal by vermifiltration, showing a positive contribution of this additional treatment stage to the decrease of wastewater organic contamination.

\subsubsection{Nitrogen}

The vermifiltration-hydroponic system showed the capacity to significantly eliminate ammonia by $99 \%$. Efficient ammonia nitrogen removal by vermifiltration has been reported in the literature $[13,20,21,23]$.

Concerning ammonia content changes during the hydroponic treatment, the starting concentrations were already very low after vermifiltration. Further reduction was observed in the hydroponic unit. The results suggest activity of ammonia-oxidizing microorganisms in the hydroponic unit. In fact, since that unit was fed with vermifilter effluent and the hydroponic tray was aerated, creating the necessary aerobic conditions, the transfer of these microorganisms from the vermifilter and further nitrification activity in the hydroponic unit will likely occur. Plants may also have contributed to the decrease in ammonia concentration, as they can take up nitrogen both in the form of ammonia and nitrate [51]. Ammonia levels in the effluent fell below the LOQ after 28 days; thus, it was not possible to quantify the removal by the weighted average approach, and $100 \%$ removal was considered.

Nitrite concentrations decreased after vermifiltration treatment to values below 0.1 mg $\mathrm{NO}_{2}-\mathrm{N} / \mathrm{L}$, the only exceptions being two days where the feed values were already particularly low. Removal efficiencies from 95 to $99 \%$ were observed, comparable to the efficiency of more sophisticated swine manure treatments such as immobilized cells' reactors [10]. Wastewater treatment by vermifiltration has been reported to favor nitrification processes [20,21,29]; the present results support those observations.

Nitrite content showed a general decrease along the hydroponic treatment. Like with ammonia, nitrite decrease suggests possible activity of nitrite-oxidizing microorganisms transferred from the vermifilter by the liquid flow and proliferating in the hydroponic tray under the created aerobic conditions. Relative removal efficiency by this treatment stage was lower than the achieved by vermifiltration, and this could again be attributed to the lower starting values. Ecological balance of all the species involved in the nitrogen cycle requires the availability of their main nutrients on a certain level, and, for this reason, all nutrients, including nitrite, should tend towards certain sustained optimal levels. The presence and activity of nitrifying micro-organisms both in the liquid phase and in biofilms within the system should be more thoroughly investigated in the future. 
Nitrate has been shown to increase due to nitrification activity in vermifilters [21,29]. For the hydroponic treatment, nitrate removal as nutrients for plants was hypothesized. Nitrate showed a relative increase after vermifiltration of just $11.0( \pm 0.8) \%$, and the hydroponic treatment caused a relative removal up to $27( \pm 3) \%$. These modest relative changes can be explained by the fact that the system was running for 28 days, and most of the volume transferred to the mixing tank corresponded to the hydroponic effluent, gathered in the final reservoir for at least seven days each time. In addition, $80 \%$ of that treated water was returned to the mixing tank along with every new sample addition. The observed nitrate accumulation is also consistent with nitrifying microorganisms' spread and activity throughout the system. Final effluent had higher nitrate concentrations than the accepted values for wastewater discharge or recommended for irrigation purposes, according to Portuguese law (50 mg NO $3 / \mathrm{L}$, corresponding to $11 \mathrm{mg} \mathrm{NO}_{3}-\mathrm{N} / \mathrm{L}$ ) [49]. These observations suggest that the use of the final effluent as dilution water may be counterproductive for nitrate removal. Another likely factor contributing to limited nitrate removal might be an unbalanced nutrient content in the vermifiltered wastewater, impairing plant metabolism. A thorough characterization and nutrient correction of such media should significantly improve the plants' growth and therefore nitrogen uptake.

\subsubsection{Phosphorus}

Total and dissolved phosphorus were analyzed in the hydroponic feed and effluent in order to assess the removal capacity of the hydroponic unit. Both total and dissolved phosphorus showed a significant decrease as determined by the applied method, suggesting that hydroponic systems can be successfully used to remove phosphorus from wastewaters. Hydroponic cultivation thus presents itself as a promising technique for phosphorus removal from wastewaters, provided that sufficiently resistant plants are grown and better conditions are created. As was observed for nitrate, correcting nutrient content in the vermifiltered wastewater and providing an optimized light spectrum and intensity for photosynthesis might improve phosphorus remediation and generate an effluent with a much lower eutrophication potential.

\subsection{Coliform Bacteria}

Coliforms were analyzed in the wastewater by CFU counting after several weeks of operation in order to examine the system in a mature state. Diluted samples from the vermifilter feed, vermifilter effluent/hydroponic feed, hydroponic effluent, and final holding reservoir, taken in 1-mL aliquots, did not provide useful counts. Based on the analysis of undiluted samples, vermifiltration resulted in a reduction of coliform bacteria by $54 \%$. Elimination of coliforms by vermifiltration has been reported before $[18,21,28,52]$. Vermifiltration coliforms removal efficiency was reported to increase exponentially with environment temperature, reaching $100 \%$ at $34{ }^{\circ} \mathrm{C}$ and 45 to $60 \%$ at 20 to $25{ }^{\circ} \mathrm{C}$ [52], which corresponded to the system operation conditions in this work. Coliform removal efficiency should, therefore, be improved by setting and keeping the vermifilter at a higher temperature. The hydroponic treatment, also operating at room temperature, contributed to reverse the initial removal effect, increasing coliform content by $56 \%$ relative to the vermifilter effluent; the treated water reservoir showed a further increase by $55 \%$ (Figure 3), reaching final counts significantly above the maximum limits for any water use, imposed by Portuguese law (maximum 500 per $100 \mathrm{~mL}$, depending on the intended use) [49]. Presumably, the long hydroponic residence time and the additional storage of the treated water in a reservoir gave the bacterial population a chance to grow. The return of reservoir water to vermifilter feed at 80 to $90 \%$ contributed, in turn, to higher feed coliform loads. The observation that using coliform-contaminated wastewaters for hydroponic growth can provide good proliferation conditions and increase coliform contamination of the final effluent is a threat to the goal of reusing vermifiltered wastewater for edible crop production. However, this should be easier to address in hydroponic systems than in 
soil-based agriculture. Water decontamination by ultraviolet light after vermifiltration might be a solution to this problem.

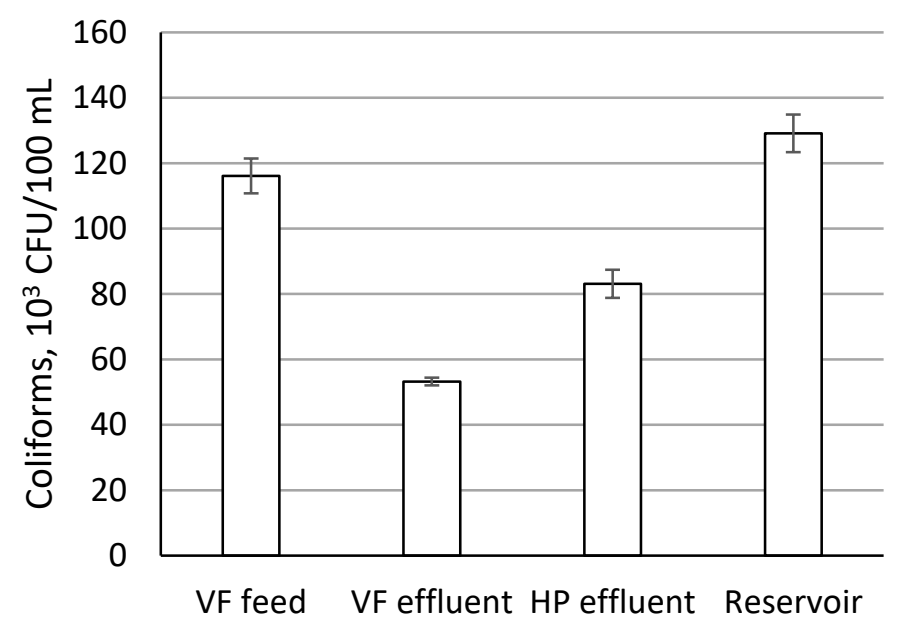

Figure 3. Total coliforms in wastewater at different process stages.

\subsection{Behavior of the Hydroponically Growing Crops}

The plants showed measurable growth of aerial parts length and diameter, stem height, and number of leaves; however, the mean aerial diameter showed a decrease after 28 days, and the number of leaves stagnated at that point (Figure 4). Visual analysis also showed problems due to deficiencies in nutrients such as, at least, iron and magnesium: yellowing of younger leaves between veins, and potassium: leaves dying at the tips, leaves curling [53] (Figure 5). The results suggest that diluted and vermifiltered piggery wastewater as was used in this study did not provide all the necessary nutrients for plant growth and development. The use of diffuse natural daylight for plant photosynthesis, may have also contributed to reduce nutrient absorption. Quantitative analysis of such wastewaters for the essential nutrients and supplementation as needed could be essential to allow for growth of healthy, nutritious crops with metabolic capacity to efficiently remove the target pollutants: inorganic nitrogen and phosphorus.

\subsection{System Limitations and Future Improvements}

A system combining a vermifilter with a downstream hydroponic unit was used in this work for hog farm wastewater treatment. The use of hydroponic cultures in this study was tested for two main goals: removing eutrophicating contaminants from the vermifiltered wastewater and obtaining nutritious crops for human and/or animal consumption. A third goal was to save as much water as possible by reusing the final effluent for dilution. The obtained results suggest an interesting potential for both wastewater treatments and the production of marketable crops. The hydroponic plant cultures showed the capacity to remove inorganic phosphorus and nitrate from previously vermifiltered wastewater, provided that a good plant health and growth rate are ensured and contributing to the enhanced treatment of wastewater.

To successfully attain both the wastewater treatment and crop production goals, the plants should be able to grow abundantly while consuming most of the nitrogen and phosphorus in the water. Not every crop is probably adequate for this function, and a comprehensive study must first address the crop selection problem. It is also critical to regularly control the nutrient composition of the vermifiltered water to be fed to the hydroponic cultures, since the swine wastewater will vary in composition, and so will the vermifilter effluents. The vermifilter effluent should be thoroughly analyzed for all the important nutrients, including the chemical forms of nitrogen, phosphorus, and sulphur, and other elements such as magnesium, potassium, calcium, manganese, iron, copper, zinc, and others. As was observed, vermifilter effluent $\mathrm{pH}$ can change over time 
due to a complexity of factors, and EC tends to increase with increasing mineralization of recirculating wastewater. For each specific crop, the ideal medium composition, EC and $\mathrm{pH}$ should be known, and the feed corrected as necessary. Saving water through effluent recirculation should be feasible by introducing additional treatment modules for the removal of accumulated components. Temperature and moisture control in the facilities, as well as controlled light for photosynthesis, are other important requirements for optimized hydroponic crop production.

Vermifiltered wastewater use as nutrient medium for hydroponic growth might be compromised by the proliferation of pathogens such as coliform bacteria and subsequent contamination of crops. Microorganisms, both those introduced with the wastewater and those growing within the system, should be characterized and controlled by periodic decontamination using ultraviolet light irradiation.

The system might benefit greatly from the use of a community of plant species with different capacities and requirements. Once enough knowledge is available, it should be possible to develop the best hydroponic system configurations and plant species selection, combination and disposition within the hydroponic units. Possibly, non-nutritious plants must be used in a final treatment stage to remove most of the eutrophication-inducing pollutants remaining after feeding the commercial crops.

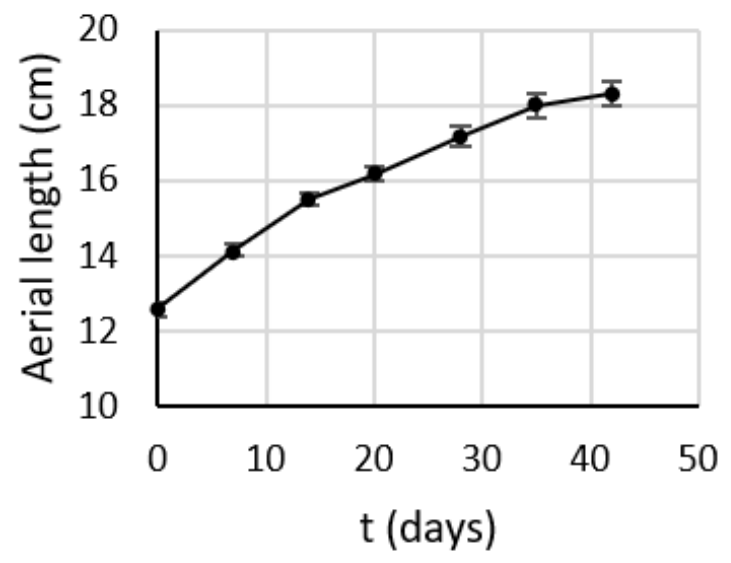

(a)

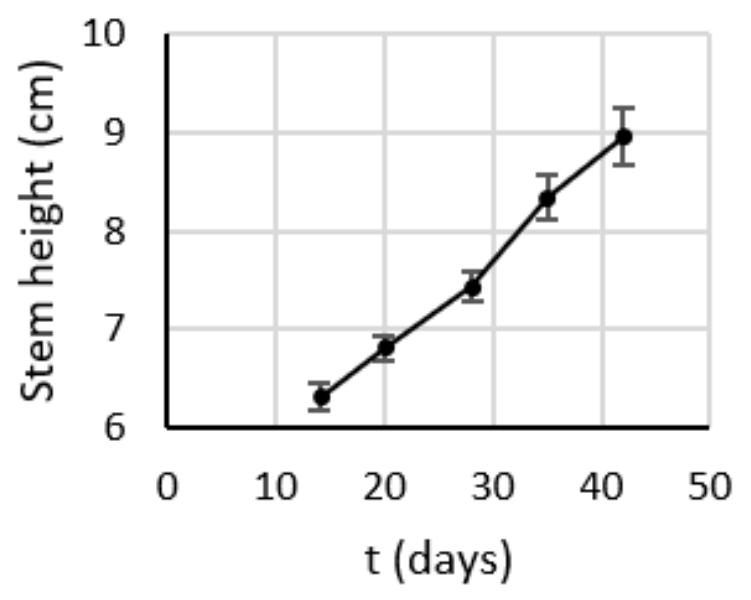

(c)

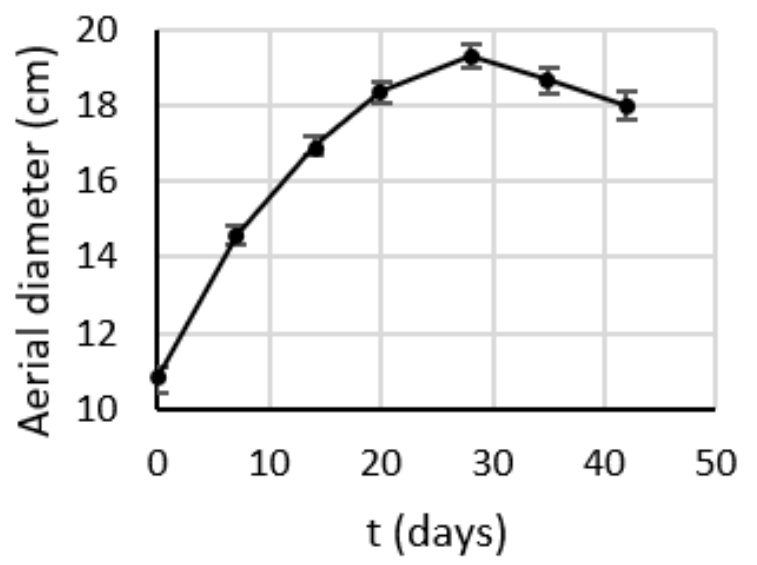

(b)

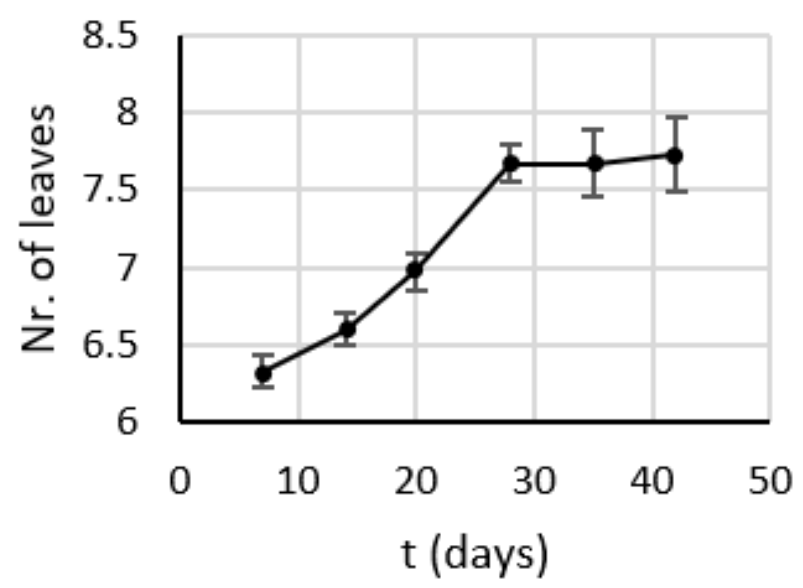

(d)

Figure 4. Growth of hydroponically cultivated crops: (a) aerial parts length; (b) aerial parts spread; (c) stem height; (d) number of leaves. 


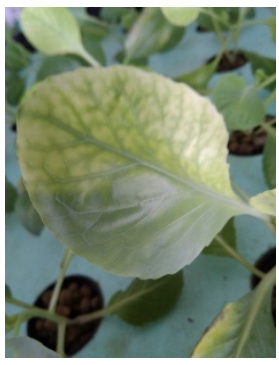

(a)

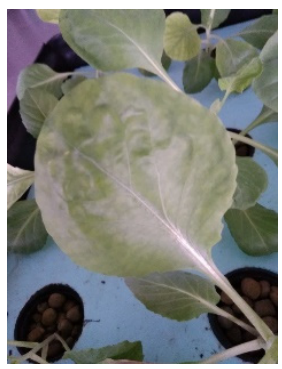

(b)

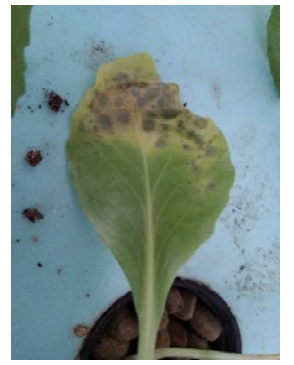

(c)

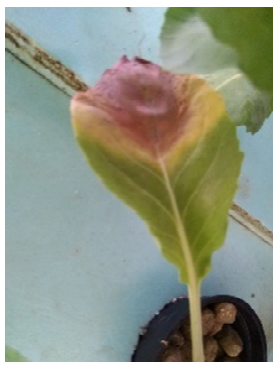

(d)

Figure 5. Evidence of nutrient deficiency observed on cabbage leaves: (a) leaf yellowing in-between veins; (b) leaf blade wrinkling; (c,d) blade tip necrosis.

The implementation of similar systems on real scale will bring up further challenges. One potential setback could be the additional land use for hydroponic cultures; however, hydroponic cultivation can be designed to reduce land use by using vertical space, unlike traditional agriculture. Water treatment efficiency will depend on the liquid flow and the volume of each compartment. Slower flows and larger volumes will increase hydraulic residence times and conversion efficiency. On the other hand, slower flows will limit the throughput and could be useless in real hog farms. Large reactor volumes occupy more space and imply higher installation costs, electrical power for pumps, aeration, stirring and automation, maintenance of all structures and equipment. Qualified personnel will be needed, especially in large-scale facilities.

\section{Conclusions}

A working pilot-scale system was built, combining vermifiltration with hydroponic crop cultivation for hog farm wastewater treatment and reusing part of the treated effluent as feed dilution water. Vermifiltration treatment was able to efficiently remove ammonia, nitrite, and $\mathrm{BOD}_{5}$ from the wastewater, and nitrate accumulation was observed. Coliform bacteria were reduced by $54 \%$ by vermifiltration. Hydroponic treatment of vermifiltered wastewater was able to remove phosphorus and, modestly, nitrate under the studied conditions. A further decrease in $\mathrm{BOD}_{5}$ was observed due to the hydroponic treatment. Nitrite and nitrate tended to stabilize at certain levels over time due to final effluent reuse for feed dilution. Coliforms were able to recover in the hydroponic unit, suggesting the need to control their population. Pointed cabbage (Brassica oleracea L., var. capitata) was able to grow on vermifiltered swine wastewater, diluted 10-fold with reused final effluent, as long as its nutritional requirements were met.

The proposed system aimed to treat piggery wastewater, while producing commercial crops. Efficient water treatment implies the removal of most pollutants, while good crop productivity needs excess nutrients to be present in the hydroponic medium. To ensure both, a very good knowledge of the crops' needs and control of medium composition are necessary. Continuous systems with effluent recirculation and long hydraulic residence times create additional complications for efficient nitrogen removal and microbiological safety. However, the present study shed light on several important aspects that can be henceforth addressed through batch optimization of biological components and physicochemical conditions, followed by implementation and control in continuous systems.

Scale-up for implementation at real hog farms will require careful sizing to optimize both the throughput and treatment efficiency, and investment in equipment, electrical power, and workforce will be required. Overall, the tested system showed positive perspectives of the use of vermifilters coupled with downstream hydroponic cultivation units as biological solutions for the treatment of animal farming effluents and other heavily contaminated wastewaters. 
Author Contributions: Conceptualization, K.I. and L.M.I.A.; methodology, K.I. and L.M.I.A.; validation, K.I., L.M.I.A., N.D.L., and J.S.V.; formal analysis, K.I.; investigation, K.I. and L.M.I.A.; resources, K.I., L.M.I.A., and J.S.V.; writing—original draft preparation, K.I.; writing—review and editing, K.I., L.M.I.A., N.D.L., and J.S.V.; visualization, K.I.; supervision, L.M.I.A. and N.D.L.; project administration, J.S.V.; funding acquisition, J.S.V. and N.D.L. All authors have read and agreed to the published version of the manuscript.

Funding: This work was supported by Base Funding-UIDB/50020/2020 of the Associate Laboratory LSRE-LCM, funded by national funds through FCT/MCTES (PIDDAC), and by the Applied Molecular Biosciences Unit-UCIBIO, which is financed by national funds from FCT (UIDP/04378/2020 and UIDB/04378/2020).

Institutional Review Board Statement: Not applicable.

Informed Consent Statement: Not applicable.

Data Availability Statement: Not applicable.

Conflicts of Interest: The authors declare no conflict of interest.

\section{References}

1. Food and Agricultural Organization. FAOSTAT. Available online: http://www.fao.org/faostat/en/\#home (accessed on 9 April 2021).

2. INE Instituto Nacional de Estatística-Statistics Portugal. Available online: https://www.ine.pt/xportal/xmain?xpid=INE\& xpgid=ine_main (accessed on 9 April 2021).

3. Backus, G.; Van Wagenberg, C.; Verdoes, N. Environmental impact of pig meat production. Meat Sci. 1998, 49, S65-S72. [CrossRef]

4. Zhang, D.; Wang, X.; Zhou, Z. Impacts of Small-Scale Industrialized Swine Farming on Local Soil, Water and Crop Qualities in a Hilly Red Soil Region of Subtropical China. Int. J. Environ. Res. Public Health 2017, 14, 1524. [CrossRef]

5. Choudhary, M. Review of the Use of Swine Manure in Crop Production: Effects on Yield and Composition and on Soil and Water Quality. Waste Manag. Res. 1996, 14, 581-595. [CrossRef]

6. Chelme-Ayala, P.; El-Din, M.G.; Smith, R.; Code, K.R.; Leonard, J. Advanced treatment of liquid swine manure using physicochemical treatment. J. Hazard. Mater. 2011, 186, 1632-1638. [CrossRef]

7. Zublena, J.P.; Barker, J.C. Nutrient Assessment and Distribution of Animal Manure. Better Crop. 1992, Summer, $28-31$.

8. Jaramillo, M.F.; Restrepo, I. Wastewater Reuse in Agriculture: A Review about Its Limitations and Benefits. Sustainability 2017, 9, 1734. [CrossRef]

9. FSA. Environmental Alternative Systems for Piggery Effluent Treatment; FSA: Queensland, Australia, 2000.

10. Szögi, A.A.; Vanotti, M.B.; Rice, J.M.; Humenik, F.J.; Hunt, P.G. Nitrification options for pig wastewater treatment. N. Z. J. Agric. Res. 2004, 47, 439-448. [CrossRef]

11. De La Mora-Orozco, C.; González-Acuña, I.J.; Saucedo-Terán, R.A.; Flores-López, H.E.; Rubio-Arias, H.O.; Ochoa-Rivero, J.M. Removing Organic Matter and Nutrients from Pig Farm Wastewater with a Constructed Wetland System. Int. J. Environ. Res. Public Health 2018, 15, 1031. [CrossRef]

12. Garg, V.K.; Yadav, Y.K.; Sheoran, A.; Chand, S.; Kaushik, P. Livestock excreta management through vermicomposting using an epigeic earthworm Eisenia foetida. Environmentalist 2006, 26, 269-276. [CrossRef]

13. Li, Y.; Robin, P.; Cluzeau, D.; Bouche, M.; Qiu, J.; Laplanche, A.; Hassouna, M.; Morand, P.; Dappelo, C.; Callarec, J. Vermifiltration as a stage in reuse of swine wastewater: Monitoring methodology on an experimental farm. Ecol. Eng. 2008, 32, 301-309. [CrossRef]

14. Singh, R.; Bhunia, P.; Dash, R.R. A mechanistic review on vermifiltration of wastewater: Design, operation and performance. J. Environ. Manag. 2017, 197, 656-672. [CrossRef]

15. Samal, K.; Dash, R.R.; Bhunia, P. Treatment of wastewater by vermifiltration integrated with macrophyte filter: A review. J. Environ. Chem. Eng. 2017, 5, 2274-2289. [CrossRef]

16. Arora, S.; Rajpal, A.; Bhargava, R.; Pruthi, V.; Bhatia, A.; Kazmi, A. Antibacterial and enzymatic activity of microbial community during wastewater treatment by pilot scale vermifiltration system. Bioresour. Technol. 2014, 166, 132-141. [CrossRef]

17. Gupta, R.; Garg, V. Stabilization of primary sewage sludge during vermicomposting. J. Hazard. Mater. 2008, 153, 1023-1030. [CrossRef]

18. Yadav, K.D.; Tare, V.; Ahammed, M.M. Vermicomposting of source-separated human faeces for nutrient recycling. Waste Manag. 2010, 30, 50-56. [CrossRef]

19. Sinha, R.K.; Bharambe, G.; Bapat, P. Removal of high BOD and COD loadings of primary liquid waste products from dairy industry by vermi-filtration technology using earthworms. Indian J. Environ. Prot. 2007, 27, 486-501.

20. Lourenço, N.; Nunes, L. Optimization of a vermifiltration process for treating urban wastewater. Ecol. Eng. 2017, 100, 138-146. [CrossRef] 
21. Lourenço, N.; Nunes, L.M. Is filter packing important in a small-scale vermifiltration process of urban wastewater? Int. J. Environ. Sci. Technol. 2017, 14, 2411-2422. [CrossRef]

22. Rajpal, A.; Arora, S.; Bhatia, A.; Kumar, T.; Bhargava, R.; Chopra, A.; Kazmi, A. Co-treatment of organic fraction of municipal solid waste (OFMSW) and sewage by vermireactor. Ecol. Eng. 2014, 73, 154-161. [CrossRef]

23. Wang, L.; Luo, X.; Zhang, Y.; Chao, J.; Gao, Y.; Zhang, J.; Zheng, Z. Community analysis of ammonia-oxidizing Betaproteobacteria at different seasons in microbial-earthworm ecofilters. Ecol. Eng. 2013, 51, 1-9. [CrossRef]

24. Huang, K.; Xia, H.; Cui, G.; Li, F. Effects of earthworms on nitrification and ammonia oxidizers in vermicomposting systems for recycling of fruit and vegetable wastes. Sci. Total Environ. 2017, 578, 337-345. [CrossRef]

25. Castillo, J.M.; Romero, E.; Nogales, R. Dynamics of microbial communities related to biochemical parameters during vermicomposting and maturation of agroindustrial lignocellulose wastes. Bioresour. Technol. 2013, 146, 345-354. [CrossRef] [PubMed]

26. Nielsen, P.H.; Daims, H.; Lemmer, H. FISH Handbook for Biological Wastewater Treatment-Identification and Quantification of Microorganisms in Activated Sludge and Biofilms by FISH; IWA Publishing: London, UK; New York, NY, USA, 2009.

27. Andleeb, S.; Ejaz, M.; Awan, U.A.; Ali, S.; Kiyani, A.; Shafique, I.; Zafar, A. Short Communication-In vitro screening of mucus and solvent extracts of Eisenia foetida against human bacterial and fungal pathogens. Pak. J. Pharm. Sci. 2016, $29,969-977$. [PubMed]

28. Edwards, C.A.; Fletcher, K. Interactions between earthworms and microorganisms in organic-matter breakdown. Agric. Ecosyst. Environ. 1988, 24, 235-247. [CrossRef]

29. Wang, N.; Nie, E.; Luo, X.; Yang, X.; Liu, Q.; Zheng, Z. Study of nitrogen removal performance in pilot-scale multi-stage vermi-biofilter: Operating conditions impacts and nitrogen speciation transformation. Environ. Earth Sci. 2015, 74, 3815-3824. [CrossRef]

30. Suthar, S. Vermicomposting of vegetable-market solid waste using Eisenia fetida: Impact of bulking material on earthworm growth and decomposition rate. Ecol. Eng. 2009, 35, 914-920. [CrossRef]

31. Garg, P.; Gupta, A.; Satya, S. Vermicomposting of different types of waste using Eisenia foetida: A comparative study. Bioresour. Technol. 2006, 97, 391-395. [CrossRef]

32. Bawiec, A. Efficiency of nitrogen and phosphorus compounds removal in hydroponic wastewater treatment plant. Environ. Technol. 2018, 40, 2062-2072. [CrossRef]

33. Jin, E.; Cao, L.; Xiang, S.; Zhou, W.; Ruan, R.; Liu, Y. Feasibility of using pretreated swine wastewater for production of water spinach (Ipomoea aquatic Forsk.) in a hydroponic system. Agric. Water Manag. 2020, 228, 105856. [CrossRef]

34. Mavrogianopoulos, G.; Vogli, V.; Kyritsis, S. Use of wastewater as a nutrient solution in a closed gravel hydroponic culture of giant reed (Arundo donax). Bioresour. Technol. 2002, 82, 103-107. [CrossRef]

35. Kumar, C.; Ghosh, A.K. Fabrication of a vermifiltration unit for wastewater recycling and performance of vermifiltered water (vermiaqua) on onion (Allium cepa). Int. J. Recycl. Org. Waste Agric. 2019, 8, 405-415. [CrossRef]

36. Pereira, L.M.G.; Vieira, J.S.; Aires, L.M.I. Vermifiltração como meio de depuração de águas residuais de explorações suinícolas. In Proceedings of the SGA'19: Sustentabilidade na Gestão Ambiental. Inovação e Desafios para os Países de Língua Oficial Portuguesa. Centro de Congressos do Técnico, Fundec/IST, Lisboa, Portugal, 4-5 June 2019; pp. 101-108.

37. Guzyte, G.; Sujetoviene, G.; Zaltauskaite, J. Effects of salinity on Earthworm (Eisenia Fetida). In Proceedings of the 8th International Conference on Environmental Engineering (ICEE 2011), Vilnius, Lithuania, 19-20 May 2011.

38. Sinha, R.K.; Bharambe, G.; Chaudhari, U. Sewage treatment by vermifiltration with synchronous treatment of sludge by earthworms: A low-cost sustainable technology over conventional systems with potential for decentralization. Environmentalist 2008, 28, 409-420. [CrossRef]

39. ISO. Water Quality_Determination of Biochemical Oxygen Demand after $n$ Days (BODn)_Part 1: Dilution and Seeding Method with Allylthiourea (ISO Standard 5815-1:2019); ISO: Geneva, Switzerland, 2019.

40. United States Environmental Protection Agency. Method 352.1: Nitrogen, Nitrate (Colorimetric, Brucine) by Spectrophotometer; EPA: Washington, DC, USA, 1971.

41. APHA/AWWA/WEF. Standard Methods for the Examination of Water and Wastewater, 21st ed.; APHA-AWWA-WEF: Washington, DC, USA, 2005; ISBN 0875532357.

42. ISO. Water Quality—Determination of Ammonium—Part 1: Manual Spectrometric Method (ISO Standard 7150-1:1984); ISO: Geneva, Switzerland, 1984.

43. Millipore. 81938 Coliform ChromoSelect Agar Datasheet; Millipore: Darmstadt, Germany, 2018.

44. Singh, H.; Dunn, B. Electrical Conductivity and $p H$ Guide for Hydroponics; Oklahoma State University: Stillwater, OK, USA, 2016.

45. De Lira, R.M.; Da Silva, G.F.; Dos Santos, A.N.; Rolim, M.M. Production, water consumption and nutrient content of Chinese cabbage grown hydroponically in brackish water. Rev. Ciênc. Agron. 2015, 46, 497-505. [CrossRef]

46. Rahimi, G.; Karimi, F. The prolonged effect of salinity on growth and/or survival of earthworm Eisenia fetida. Int. J. Environ. Waste Manag. 2016, 18, 58-67. [CrossRef]

47. Hughes, R.J.; Nair, J.; Ho, G. The toxicity of ammonia/ammonium to the vermifiltration wastewater treatment process. Water Sci. Technol. 2008, 58, 1215-1220. [CrossRef] [PubMed]

48. Le, T.T.H.; Fettig, J.; Meon, G. Kinetics and simulation of nitrification at various $\mathrm{pH}$ values of a polluted river in the tropics. Ecohydrol. Hydrobiol. 2019, 19, 54-65. [CrossRef]

49. Ministério do Ambiente. Decreto-Lei no 236/98, de 1 de Agosto; Ministério do Ambiente: Lisboa, Portugal, 1998. 
50. Ministério do Ambiente. Decreto-Lei no 152/97, de 19 de Junho; Ministério do Ambiente: Lisboa, Portugal, 1997.

51. Masclaux-Daubresse, C.; Daniel-Vedele, F.; Dechorgnat, J.; Chardon, F.; Gaufichon, L.; Suzuki, A. Nitrogen uptake, assimilation and remobilization in plants: Challenges for sustainable and productive agriculture. Ann. Bot. 2010, 105, 1141-1157. [CrossRef]

52. Arora, S.; Kazmi, A. The effect of seasonal temperature on pathogen removal efficacy of vermifilter for wastewater treatment. Water Res. 2015, 74, 88-99. [CrossRef]

53. Marulanda, C.; Izquierdo, J. Popular Hydroponic Gardens; FAO Regional Office for Latin America and the Caribbean: Santiago, Chile, 1993. 